\title{
PRÁTICA DOCENTE EM FOCO: UM ESTUDO SOBRE INTEGRAÇÃO DOS SABERES NA EDUCAÇÃO DO CAMPO
}

\author{
TEACHING PRACTICE IN FOCUS: A STUDY ON THE \\ INTEGRATION OF KNOWLEDGE IN FIELD EDUCATION
}

PRÁCTICA DOCENTE EN FOCO: UN ESTUDIO SOBRE
INTEGRACIÓN DE LOS SABERES EN LA EDUCACIÓN DEL CAMPO

Maria Joselma do Nascimento Franco ${ }^{1}$ Maria Madalena da Silva ${ }^{1}$

Universidade Federal de Pernambuco (UFPE), Caruaru/PE - Brasil ${ }^{1}$

Resumo A pesquisa tem por objetivo compreender como a integração dos saberes é tratada nas práticas docentes em escolas do campo, tomando-a como objeto da investigação. $\mathrm{O}$ aporte teórico está referenciado em Kolling (2002), Arroyo, Caldart e Molina (2004), Oliveira e Lima $(2011,2014)$, Skovsmose $(2008,2014)$, entre outros. A partir de uma abordagem qualitativa, elegeu-se, como contexto, um município de pequeno porte em Pernambuco, buscando identificar no cotidiano escolar indícios dessa integração. Os procedimentos adotados para a coleta de dados foram a entrevista, a observação participante e a análise documental e os dados foram tratados a partir da análise de conteúdo (BARDIN, 2004), pela técnica de análise categorial. Os resultados indicam que as professoras apresentam elementos referentes aos saberes socialmente construídos no contexto, mas não promovem sua articulação com os conteúdos escolares. Dessa forma, mesmo sendo a integração de saberes uma especificidade da escola do campo, não há indícios que ela se materialize no cotidiano escolar.

Palavras-chave: Educação do campo; Integração dos saberes; Prática docente. 
Abstract The research aims to understand how the integration of knowledge is dealt with in teaching practices in rural schools. It takes as its object the integration of knowledge in teaching practice. The theoretical contribution is referenced in Kolling (2002), Arroyo, Caldart and Molina (2004), Oliveira e Lima $(2011,2014)$, Skovsmose $(2008,2014)$ among others. Based on the qualitative approach, the research took as context the municipality of São Caetano-PE, sought to identify indications of this integration of knowledge in the practice of teachers. The procedures adopted for data collection were interview, participant observation and documentary analysis. The data were treated from the content analysis (BARDIN 2004), by the technique of categorial analysis. The results show that even the integration of knowledge is a specificity of the rural school, it is not treated in the teaching practice of these schools, in the context investigated. The teachers present elements related to the socially constructed knowledge in the context, but there is no articulation with the school contents, which points to the lack of evidence to prove the integration of knowledge in the practices of teachers working in rural schools.

Keywords: Education of the field; Integration of KNOWLedge; Teaching PRactice.

Resumen La investigación tiene por objetivo comprender cómo la integración de los saberes es tratada en las prácticas docentes en escuelas del campo. Toma como objeto la Integración de los saberes en la práctica docente. El aporte teórico está referenciado en Kolling (2002), Arroyo, Caldart y Molina (2004), Oliveira y Lima (2011, 2014), Skovsmose $(2008,2014)$ entre otros. En el enfoque cualitativo, la investigación tomó como contexto el municipio de São Caetano-PE, buscó identificar indicios de esta integración de saberes en la práctica de los / las docentes. Los procedimientos adoptados para la recolección de datos fueron la entrevista, la observación participante y el análisis documental. Los datos fueron tratados a partir del análisis de contenido (BARDIN 2004), por la técnica de análisis categorial. Los resultados muestran que incluso la integración de saberes siendo una especificidad de la escuela del campo, ésta no es tratada en la práctica docente de estas escuelas, en el contexto investigado. Las profesoras presentan elementos referentes a los saberes socialmente construidos en el contexto, pero hay ausencia de articulación con los contenidos escolares, lo que apunta a inexistencia de indicios que comprueban la integración de saberes en las prácticas de las docentes actuantes en escuelas del campo.

Palabras clave: Educación del Campo; Integración de los saberes; Prácticas de los DOCENTES.

\section{INTRODUÇÃo}

O texto ora apresentado é fruto de um estudo desenvolvido sobre a integração dos saberes na prática das docentes que atuam em escolas do campo. Emergiu a partir das inquietações que as reflexões em torno da educação do campo despertaram no decorrer dos apontamentos no Grupo de Estudo em Educação do Campo - GEECampo, e no Projeto 
de Iniciação Científica na Educação Básica, desenvolvidos na Universidade Federal de Pernambuco (UFPE), no Centro Acadêmico do Agreste (CAA), além dos estudos realizados em comunidades campesinas no agreste de Pernambuco. A educação do campo é aqui assumida como fenômeno da realidade brasileira, que tem como protagonistas os trabalhadores do campo e suas organizações que buscam imprimir, nas políticas educacionais, as necessidades de sua população. A educação do campo, portanto, é também concebida enquanto prática social, alimentadora da consciência de mudança por ela projetada (CALDART, 2012).

A partir dos estudos já descritos, identifica-se que a temática da educação do campo apresenta a necessidade de integrar às práticas docentes desenvolvidas nas escolas do campo aspectos relacionados aos saberes oriundos do contexto social no qual a escola está inserida, compreendendo que o campo é um território de onde emerge cultura própria historicamente marcada por embates pela implementação de políticas públicas, por exemplo, a reforma agrária. Nota-se que um dos focos dessa luta é a demanda por uma educação comprometida com uma escola do campo, no campo e para o campo, a fim de que esta possa contribuir para uma mudança na histórica subalternização à qual as populações campesinas sempre foram submetidas.

Diante das demandas atuais da educação do campo e considerando que cabe ao docente provocar, instigar, valer-se dos saberes sociais e das áreas de conhecimentos abordadas nas práticas docentes, para que estas contemplem e acolham os aspectos relacionados a essa população, o presente estudo convida a refletir sobre a compreensão que os docentes das escolas do campo têm a respeito do trabalho com a integração dos saberes.

A prática docente na perspectiva de integração dos saberes se desenvolve enquanto prática social na medida em que esta emerge da legitimação dos conhecimentos culturalmente constituídos, gestados pelas populações do campo e concebidos enquanto saberes populares, que uma vez validados se articulam aos saberes escolares, pela via do currículo.

Diante do exposto, toma-se como base para a pesquisa a seguinte questão: Como a integração dos saberes é tratada nas práticas das docentes atuantes em escolas do campo? A pesquisa se propôs investigar se, e de que forma, os docentes atuantes nas escolas do campo promovem a integração dos saberes específicos da cultura em suas aulas, levando em conta o contexto social em que vivem, considerando-o como relevante ao debate em torno da especificidade da educação no campo.

Para tanto, elegeu-se como objetivo geral: Compreender como a integração dos saberes é tratada nas práticas docentes de professores atuantes em escolas do campo e enquanto objetivos específicos buscou-se identificar o que os professores, que atuam no campo, entendem por integração dos saberes além de analisar, nas atividades didáticas produzidas, os elementos perceptíveis da integração dos saberes e, finalmente, levantar no marco regulatório indicativos da integração de saberes.

No desenvolvimento da pesquisa, dialogou-se teoricamente com Caldart (2012), Molina e Sá (2012) para tratar da Educação do Campo, definindo-a, com Kolling (2002), cuja contribuição foi explicitar a necessidade de uma prática educacional diferenciada para o 
campo, com Arroyo, Caldart e Molina (2004), que apresentam a necessidade de uma educação específica e diferenciada para esse tipo de escolas. Para discutir a relação entre a realidade dos sujeitos e a Integração de Saberes, utilizaram-se referências da semirrealidade e da realidade, propostas por Skovsmose $(2008,2014)$, e por Lima (2014).

No marco legal, trataram-se as: Diretrizes Operacionais para a Educação Básica nas Escolas do Campo, apresentando indicativos para as respectivas propostas pedagógicas enquanto para os estudos da integração dos saberes dialogou-se com a resolução $\mathrm{N}^{\circ}$. 1CNE/ CEB, DE 3 DE ABRIL DE 2002, e com a resolução complementar No. 2, de 28 de abril de 2008, o Parecer CNE/CEB Nº. 3/2008, além da Lei de Diretrizes e Bases da Educação Nacional - Lei 9.394/96.

\section{DisCUSSÃo TEÓRICA}

\section{Educação do Campo}

Educação do campo é pensada no campo, com os seus sujeitos e, portanto, emerge desse universo social, cultural e político considerando as suas especificidades, visto que são fruto de uma trajetória marcada por lutas referentes aos interesses dos que no campo vivem.

Por educação do campo, Caldart (2012) a concebe como:

[...] fenômeno da realidade brasileira atual, protagonizado pelos trabalhadores do campo e suas organizações, que visa incidir sobre a política de educação desde os interesses sociais das comunidades camponesas. Objetivo e sujeitos a remetem às questões do trabalho, da cultura, do conhecimento e das lutas sociais dos camponeses e ao embate (de classe) entre projetos de campo e entre lógicas de agricultura que têm implicações no projeto de país e de sociedade e nas concepções de política pública, de educação e de formação humana (CALDART, 2012, p. 259).

A concepção de educação do campo, já apresentada, sinaliza uma educação que nasceu de um movimento marcado pelas necessidades de seus sujeitos. Nesse contexto, as escolas do campo representam conquistas sociais e se definem a partir das contradições da luta social. Nessa direção, tem-se que:

A concepção de escola do campo nasce e se desenvolve no bojo do movimento da Educação do Campo, a partir das experiências de formação humana desenvolvidas no contexto de luta dos movimentos sociais camponeses por terra e educação. Trata-se, portanto, de uma concepção que emerge das contradições da luta social e das práticas de educação dos trabalhadores do e no campo (MOLINA; SÁ, 2012, p. 326).

Como explicitado, essa escola surgiu do movimento em prol da educação do campo para que as práticas nele desenvolvidas atendessem às necessidades de uma educação pensada no campo e para campo, o que nos leva citar Kolling (2002), quando afirma que: 
Um dos traços fundamentais que vêm desenhado a identidade deste movimento por uma educação do campo é a luta do povo do campo por políticas públicas que garantam o seu direito à educação, e a uma educação que seja no e do campo. No: o povo tem direito a ser educado no lugar onde vive; Do: o povo tem direito a uma educação pensada desde o seu lugar e com a sua participação, vinculada à sua cultura e às suas necessidades humanas e sociais (KOLLING, 2002, p. 18).

Dessa forma, nota-se a necessidade de uma prática educacional que contemple as especificidades do povo, contextualizando suas singularidades no ensino, como um todo, e apontando para a premência em contemplar os saberes desse povo, nas vivências da sala de aula.

A perspectiva de uma educação do campo que acolha a integração dos saberes sociais em sala de aula está na proposta para a sua educação básica, instituída no artigo $5^{\circ}$. das Diretrizes Operacionais para a Educação Básica nas Escolas do Campo, que diz:

As propostas pedagógicas das escolas do campo, respeitadas as diferenças e o direito à igualdade [...] contemplarão a diversidade do campo em todos os seus aspectos: sociais, culturais, políticos, econômicos, de gênero, geração e etnia (BRASIL, 2002 p. 1).

Dessa forma, explicita a necessidade de efetivar ações que promovam o desenvolvimento de uma educação do campo que leve em conta os aspectos da diversidade e as necessidades dos que nele vivem, de maneira que se potencialize uma formação em que as pessoas se percebam como condutoras da própria vida, necessidade que aponta Arroyo, quando afirma que:

A educação do campo precisa ser uma educação específica e diferenciada, isto é, alternativa. Mas, sobretudo deve ser educação, no sentido amplo de processo de formação humana, que constrói referências culturais e políticas para a intervenção das pessoas e dos sujeitos sociais na realidade, visando a uma humanidade mais plena e feliz (ARROYO; CALDART; MOLINA, 2004, p. 23).

A materialização de práticas em favor da integração dos saberes da população do campo favorece a minimização de problemas nas escolas, como o desinteresse dos sujeitos educativos, oportunizando um aprendizado real e atraente para os mesmos, o que contribui para a formação social, educacional e humana. Assim, a compreensão que as professoras atuantes nessa realidade possuem acerca da importância da integração dos saberes é fundamental para a aproximação das práticas pedagógicas vivenciadas em sala de aula com os saberes socialmente construídos no campo.

\section{A Integração dos Saberes}

A partir das referências da categoria educação do campo, tanto nos textos oficiais, quanto nos estudos desenvolvidos sobre a temática, passou-se a tratar da integração dos saberes como princípio constituinte desse tipo de educação. 
Por integração de saberes, compreende-se a articulação entre os saberes cotidianos, populares presentes na cultura local e os constituídos a partir das áreas de conhecimento presentes no currículo escolar. Essa compreensão ganha consonância com a perspectiva de constituir-se como o "diálogo entre os saberes populares" construídos na prática produtiva e social dos sujeitos do campo e os saberes científicos, técnicos e tecnológicos gerados por processos de pesquisa, registro e reflexão, com vistas à produção de novos saberes" (BRASIL, 2008, p. 15; grifos do autor).

Contempla essa perspectiva dessa integração a metodologia da alternância, "[...] desenvolvida pela conjugação de períodos alternados de formação na escola e na família e pelo uso de instrumentos pedagógicos específicos" (BRASIL, 2008, p. 62), sendo essa metodologia uma especificidade do campo que poderá auxiliar na integração de saberes, que se expressa na articulação entre os conhecimentos científicos e populares (BRASIL, 2008).

Sendo os povos do campo sujeitos de direitos, identificou-se a necessidade da efetivação de uma política educacional que respeite suas especificidades. Com essa compreensão, tem-se a RESOLUÇÃO CNE/CEB 1, DE 3 DE ABRIL DE 2002, afirmando que:

\begin{abstract}
A identidade da escola do campo é definida pela sua vinculação às questões inerentes à sua realidade, ancorando-se na temporalidade e saberes próprios dos estudantes, na memória coletiva que sinaliza futuros, na rede de ciência e tecnologia disponível na sociedade e nos movimentos sociais em defesa de projetos que associem as soluções exigidas por essas questões à qualidade social da vida coletiva no país (BRASIL, 2002, p. 1).
\end{abstract}

Reafirma-se, assim, a necessidade de reconhecer os saberes que lhes são historicamente negados, superando o preconceito em relação aos saberes socialmente construídos daqueles que vivem e trabalham no campo. A expectativa, portanto, é de construção de uma proposta educacional que promova a integração dos saberes, articulando os conteúdos curriculares propostos àqueles populares, conforme indicativo assegurado no Artigo $28^{\circ}$. da Lei de Diretrizes e Bases da Educação Nacional, Lei 9.394/96.

\footnotetext{
Na oferta de educação básica para a população rural, os sistemas de ensino promoverão as adaptações necessárias à sua adequação às peculiaridades da vida rural e de cada região, especialmente: $I$ - conteúdos curriculares e metodologias apropriadas às reais necessidades e interesses dos alunos da zona rural; II - organização escolar própria, incluindo adequação do calendário escolar às fases do ciclo agrícola e às condições climáticas; $I I I$ - adequação à natureza do trabalho na zona rural (BRASIL, 2006; grifos do autor).
}

O diálogo entre os conteúdos do currículo e os saberes populares apresenta-se como uma forma de efetivação das indicações oficiais para concretizar a educação do campo nas escolas, respeitando suas especificidades.

Nessa perspectiva, identificam-se nas produções da área práticas que sugerem integralizar o conhecimento socialmente construído no campo no ensino. Entre elas, destaca-se a 
perspectiva de Oliveira e Lima (2011, p. 48): “[...] busca integrar os saberes escolares das áreas de conhecimento e os da realidade a qual o sujeito está inserido”. Essa concepção integralizadora dos saberes influencia algumas metodologias, como é o caso da alternância pedagógica ou pedagogia da alternância.

A pedagogia da alternância é uma metodologia que envolve a perspectiva de integração dos saberes, atendendo, em suas abordagens, à relevância de considerar as especificidades do sujeito do campo como ser social, conforme explicam Teixeira, Bernartt e Trindade (2008, p. 227): “A pedagogia da alternância consiste numa metodologia de organização do ensino escolar que conjuga diferentes experiências formativas distribuídas ao longo de tempos e espaços distintos, tendo como finalidade uma formação profissional".

Percebe-se, então, que a integração dos saberes é parte constituinte da pedagogia da alternância na medida em que a metodologia possibilita a articulação dos saberes curriculares e saberes sociais, culturais e históricos enquanto possibilidade da formação de sujeitos que têm identidade com o lugar em que vivem - o campo.

\section{Prática Docente e Formação}

Prática docente e Formação na perspectiva aqui tratada se realimentam, visto que se entende que a prática docente demanda do professor o aprimoramento da autoformação. Nessa perspectiva, explicita Giesta (2001, p. 17):

[...] é importante que o professor passe a considerar que as questões postas pela prática docente, ao invés de representarem razões para desestímulo, podem ser canalizadas para incitar a busca de soluções, e que, em alguns casos, podem despertar no educador a responsabilidade com sua autoformação.

De acordo com a autora, as demandas da prática docente precisam ser tratadas pelo professor como possibilidades de novas ações, favoráveis ao desenvolvimento de sua formação, tendo em vista que o fazer do professor que assume uma postura reflexiva é guiado por aquilo que concebe, como afirma Giesta:

O conhecimento pelo próprio professor do conhecimento que utiliza para enfrentar as situações inéditas a cada dia vai exigir dele uma análise da própria prática, uma reflexão que faça emergir os recursos intelectuais implícitos nas ações que executa, no diagnóstico das situações, na escolha das estratégias e na previsão das conseqüências (sic) (2001, p. 22).

Ao assumir os desafios que emergem da prática em uma perspectiva reflexiva, o professor ganha consciência de seus limites e parte em busca de ações justificadas pelo conhecimento que adquiriu por meio das próprias experiências.

Imbernón (2010) afirma que o contexto interfere na prática docente, favorecendo ou não o desenvolvimento de ações, dependendo do tipo de postura que o professor assuma diante dos problemas encontrados. Ainda segundo o autor: 
$\mathrm{Na}$ atualidade, temos certeza de que a educação só mudará se os professores mudarem, mas os contextos em que esses interagem também deverão fazê-lo. Se o contexto não muda, podemos ter professores mais cultos e com mais conhecimento pedagógico, mas não necessariamente mais inovadores, já que o contexto pode impossibilitar-lhes o desenvolvimento da inovação ou pode levá-los a se recolherem em seus microcontextos, sem repercutirem com sua prática uma inovação mais institucional (IMBERNÓN, 2010, p. 96).

$\mathrm{O}$ autor, portanto, possibilita que se pense na necessidade de formação tanto na perspectiva macrossistêmica, a partir das políticas de formação, quanto do ponto de vista do microssistema, no âmbito escolar, que se articula ao contexto da sala de aula em que o professor assume o lugar de ator/autor social.

Reconhecendo a necessidade de uma educação diferenciada nas escolas do campo, entende-se primordial proporcionar aos/as professores/as uma formação específica para a atuação, como estabelece a Resolução $n^{0}$. 2, de 22 de abril de 2008, ao explicitar que:

A admissão e a formação inicial e continuada dos professores e do pessoal de magistério de apoio ao trabalho docente deverão considerar sempre na formação pedagógica apropriada à Educação do Campo e às oportunidades de atualização e aperfeiçoamento com os profissionais comprometidos com suas especificidades (BRASIL, 2008, p. 2; grifos do autor).

Para tanto, o respeito aos saberes dos campesinos, bem como, sua materialidade pela via curricular, expressa a importância dos mesmos serem contemplados e articulados aos conhecimentos científicos, tratados na escola, como diz Freire:

Não é possível respeito aos educandos, à sua dignidade, a seu ser formando-se, à sua identidade fazendo-se, se não se levam em consideração as condições em que eles vêm existindo, se não se conhece a importância dos "conhecimentos se experiência feitos" com que chegam à escola. O respeito devido à dignidade do educando não me permite subestimar, pior ainda zombar do saber que ele traz consigo para escola (FREIRE, 1996, p. 64).

No que diz respeito ao trabalho docente na educação básica das escolas do campo infere-se, a partir de Freire, a necessidade de interações sociais distintas com saberes e conhecimentos particulares, caso contrário, eles podem ser desconsiderados no cotidiano escolar.

A prática docente é identificada por Vasconcelos (2014, p. 58), como “[...] o exercício profissional do trabalho do professor por meio de variadas expressões carregadas de teor político-ideológico, abordadas sob diversas perspectivas". Para a autora, a prática docente é dinâmica e se constitui de uma relação entre a prática e a teoria, pois:

A prática docente é fruto da relação indissociável entre teoria e prática, e figura totalidade numa perspectiva dialética. É, também, um espaço tempo de múltiplas possibilidades de criar e transgredir as imposições advindas das políticas, diretrizes curriculares, que desejam modelá-la, conformando-a a modelos es- 
táticos e desconsiderando a sua dinamicidade e fluidez, a sua capacidade de recriação, transformação no espaço concreto em que se materializa, por meio dos desejos e intenções dos seus praticantes (VASCONCELOS, 2014, p. 63).

Segundo a autora, a prática docente abrange as decisões dos envolvidos antes mesmo do desenvolvimento da aula. Nossa opção é por desenvolver um diálogo sobre a prática docente em uma perspectiva reflexiva, que se fundamenta no que explicita Freire (1996, p. 38), ao afirmar que "A prática docente crítica, implicante do pensar certo, envolve o movimento dinâmico, dialético, entre o fazer e o pensar sobre o fazer".

Nesse sentido, nota-se a importância do olhar atento do professor mediante sua prática, ao saber lidar com valores e relações distintas, o que nos leva a refletir conforme Borges e Silva (2012, p. 210) que "[...] quando estamos desenvolvendo atividades educativas, na escola ou em outro lugar, significa que estamos tratando com ideias, que envolvem valores, maneira de sentir e pensar de pessoas e grupos".

Para discutir a articulação entre a realidade dos sujeitos e os conteúdos trabalhados no currículo, caracterizando a relação com a Integração de Saberes, utilizaram-se as referências da semirrealidade e da realidade, propostas por Skovsmose $(2008,2014)$ e por Lima (2014). A semirrealidade é discutida em Skovsmose (2008) como sendo um cenário que traz dados do contexto, mas não os problematiza, não se propõe a investigar seus produtos, apresentando-se como uma situação artificial. Já a referência de realidade é concebida, pelo mesmo autor, como cenário investigativo no qual os sujeitos educativos trabalham atividades, desenvolvem experiências que contemplam situações da vida real, construindo significados e se tornando sujeitos ativos de seus contextos. Para Lima (2014), a realidade é sinônimo de problematizar uma situação real, do contexto dos sujeitos, transformá-la em um cenário de investigação de forma a ser ressignificada pelos alunos, que se mobilizam para resolvê-la e explicá-la. Esses conceitos serão abordados na seção de análise dos dados.

\section{Desenho metodológico}

Para compreender como a integração de saberes é tratada nas práticas docentes de professores atuantes em escolas do campo, o desenvolvimento da pesquisa exigiu a abordagem qualitativa que, segundo Minayo, é aquela que "Trabalha com o universo de significados, motivos, aspirações, crenças, valores e atitudes, o que corresponde a um espaço mais profundo das relações dos processos e dos fenômenos [...]" (1994, p. 21-22).

Como procedimentos para a coleta de dados, foram utilizados a observação participante, a entrevista e a análise documental. Optou-se pela observação participante pela aproximação que ela possibilita do pesquisador com o contexto pois, segundo Lüdke e André, a observação participante "É uma estratégia que envolve, pois, não só a observação direta mas todo um conjunto de técnicas metodológicas pressupondo um grande envolvimento do pesquisador na situação estudada" (1986, p. 28).

Segundo Lüdke e André (1986, p. 34), “A grande vantagem da entrevista sobre outras técnicas é que ela permite a captação imediata e corrente da informação desejada, pratica- 
mente com qualquer tipo de informante e sobre os mais variados tópicos" e foi utilizada para responder ao objetivo de identificar o que os professores que atuam no campo sabem sobre a integração dos saberes.

Para contemplar os objetivos de analisar nas atividades didáticas produzidas os elementos perceptíveis da integração dos saberes e de levantar no marco regulatório indicativos da integração de saberes, fez-se uso da análise documental, compreendendo-a como: "[...] técnica valiosa de abordagem de dados qualitativos, seja completando as informações obtidas por outras técnicas, seja desvelando aspectos novos de um tema ou problema" (ANDRÉ E. LÜDKE, 1986, p. 38).

Os documentos selecionados foram do "tipo pessoal", visto que se trata das atividades dos alunos propostas pelas professoras e do "tipo oficial" ao tratar do marco regulatório. $\mathrm{O}$ tratamento dos dados se deu a partir da análise conteúdo, que para Bardin, “[...] procura conhecer aquilo que está por trás das palavras sobre as quais se debruça. [...] a análise de conteúdo é uma busca de outras realidades através das mensagens" (BARDIN, 2004, p. 38).

Como campo empírico, foram eleitas duas escolas públicas de um município no agreste pernambucano localizadas no território rural e cujas atividades produtivas são, entre outras, a agricultura de subsistência e a pecuária. As escolas estão em regiões distintas da cidade localizando-se a primeira delas a $8 \mathrm{~km}$ do marco zero da cidade e a segunda a $4,5 \mathrm{~km}$.

Na primeira comunidade, encontram-se lavouras com predominância no cultivo de mandioca e milho, identifica-se também a emergência da costura atividade que predomina principalmente entre os mais jovens e em períodos de estiagem. A sala observada nessa escola é multisseriada e contempla o $3^{\circ}$. e $4^{\circ}$. anos, sendo a turma composta por 14 alunos na faixa etária entre 8 e 9 anos. A professora, oriunda das escolas do campo do referido município, tem formação no Normal Médio e cursava Licenciatura em Pedagogia, não vinculada ao campo, no período desta pesquisa, atuava havia três anos na docência, sendo, o primeiro deles na educação do campo.

A segunda escola está localizada em um sítio às margens da estrada de acesso à cidade. Nela há os segmentos destinados à educação infantil e aos anos iniciais do ensino fundamental, com um quantitativo aproximado de 73 alunos, nos turnos da manhã e tarde. A estrutura física se apresenta conservada, a sala é arejada e iluminada. Materiais didáticos e jogos pedagógicos são expostos em cantos definidos da sala.

A sala de aula observada é multisseriada e contempla o $4^{\circ}$. e $5^{\circ}$. ano, a turma é composta por 18 alunos com a faixa etária entre 9 e 10 anos. A professora tem graduação em Pedagogia e seu curso não foi vinculado à educação do campo. No período da pesquisa, cursava pós-graduação latu sensu. Tinha 13 anos de docência, sendo o investigado o primeiro ano de atuação na escola do campo.

Para preservar a identidade, as instituições e o município não foram nomeados. As professoras foram citadas como PI e PII. Para eleger as escolas, foi consultada a secretaria de educação municipal e, após obtida autorização, seguiu-se para a reunião com o grupo de professoras que atuam nas escolas do campo, para a apresentação da pesquisa. Duas pro- 
fessoras se disponibilizaram a participar, contemplando comunidades campesinas distintas. Dessa forma, resulta que a seleção foi por aceite e, desse modo, aleatória.

As entrevistas foram realizadas individualmente, sendo que o período de levantamento de dados na escola se deu de setembro a novembro de 2014 e recaiu em duas salas de aula multisseriadas. Foram também selecionadas atividades nos cadernos dos alunos, além de trechos do diário das professoras nos quais se identificou uma relativa integração de saberes.

A análise documental se deu a partir da seleção dos documentos que tratavam da especificidade da educação nas escolas do campo, foram eles: Parecer CNE/CEB N ${ }^{\circ}$. 23/2007; Resolução $\mathrm{N}^{\circ}$. 02, de 28 de abril de 2008; Decreto $\mathrm{N}^{\circ}$. 7.352, de 4 de novembro de 2010; cadernos da SECAD, 2007; Resolução CNE/CEB Nº. 01, de 3 de abril de 2002; e Parecer CNE/CEB No. 3, de 18 de fevereiro de 2008. Para tratá-los, tomou-se como foco o procedimento da análise categorial ou temática, selecionando os extratos que situavam a especificidade da educação do campo, enquanto cenário constitutivo para a possível integração de saberes.

A observação participante se deu fundamentada em André (1998), que afirma ser a observação participante desenvolvida a partir da inserção do pesquisador em campo, de sua interação e de suas contribuições ao contexto da investigação. Foram realizadas 10 sessões de observação, contemplando quatro horas em cada escola, nas salas multisseriadas. Foram selecionados dois cadernos de alunos em cada uma delas. O critério de seleção dos cadernos foi que apresentassem todas as atividades do ano letivo de 2014 completos.

No tratamento das atividades, tomou-se como descritor para a análise das atividades "a integração de saberes" pautada nos conceitos de referência de realidade e Semirrealidade fundamentada em Skovsmose $(2008,2014)$ e Lima (2014).

Para a análise dos dados, propôs-se um diálogo entre a prática docente, as atividades didáticas e os depoimentos dos sujeitos, atentando para a relação destes com a integração de saberes.

Conforme Bardin (2004), trabalhou-se a análise categorial ou temática. Para tanto, foram levantadas as temáticas comuns às entrevistas, no que diz respeito à formação dos professores na educação do campo e sua relação ou não, com a integração de saberes, de onde emergiu a primeira categoria de análise, a saber: Integração de saberes e formação de professores: elementos que se aproximam e se distanciam.

Adotando o mesmo procedimento de eleger as temáticas comuns, e considerando que os dois sujeitos concebiam que a realidade dos alunos encontrava-se contemplada nos conteúdos trabalhados, recorreu-se ao corpus da pesquisa, diários de classe das professoras participantes e atividades didáticas propostas pelas professoras aos alunos, para identificar a integração de saberes, a partir do marco regulatório Resolução 2002, 2008 e do Decreto Presidencial de 7.352/2010. Dessa forma, constituiu-se a segunda categoria de análise, a saber: Integração de saberes: do marco regulatório às atividades didáticas - que indícios encontramos nas práticas docentes?

Como já anunciado, a partir do tratamento dos dados, duas categorias analíticas emergiram, a saber: Integração de saberes e formação de professores: elementos que se apro- 
ximam e se distanciam, nas quais se tratou do olhar dos sujeitos para a formação inicial e continuada das professoras em relação à educação do campo e sobre o nível de proximidade ou distanciamento em relação à integração de saberes. Quanto à segunda categoria, Integração de saberes: do marco regulatório às atividades didáticas - que indícios encontramos nas práticas docentes?, buscou-se a Integração de Saberes a partir do corpus, citado para chegar à prática docente que passou a ser tratada a partir da classificação de referência de semirrealidade e realidade de Skovsmose (2008, 2014) e Lima (2014).

\section{AnÁlise e disCuSSÃo de dAdOS}

Tomando como referência a integração dos saberes na prática docente da educação do campo, passaremos a tratar os dados, procurando: identificar o entendimento sobre a integração dos saberes sustentado pelas professoras que atuam no campo; analisar, nas atividades didáticas produzidas, os elementos perceptíveis da integração dos saberes e levantar, no marco regulatório, indicativos da integração desses saberes, temas que serão tratados a seguir.

\section{INTEGRAÇÃO DE SABERES E FORMAÇÃO DE PROFESSORES DO CAMPO: ELEMENTOS QUE SE APROXIMAM E SE DISTANCIAM}

Por integração de saberes, tomou-se a acepção de Lima (2014), que a concebe como uma articulação entre os saberes curriculares, propostos a partir das áreas de conhecimento e os saberes não escolares, entre estes, os saberes populares construídos na experiência de vida, no trabalho, nas atividades produtivas nas organizações sociais e outros espaços.

A formação de professores é aqui tomada na perspectiva de Imbernón compreendida não apenas como "[...] aprender mais, inovar mais, mudar mais ou aquilo que se pode acrescentar aqui, mas pode ser uma arma crítica contra práticas laborais, como por exemplo, a hierarquia, o abuso de poder, a miséria econômica de muitos educadores [...]" (2010, p. 46).

No que diz respeito à formação inicial para atuar na educação do campo PI e PII, afirmam:

\footnotetext{
Não, por que é muito difícil nunca é nada voltado para a educação do campo, é como se fosse esquecida, porque até em capacitação, em tudo, nunca foca a educação do campo, nem dá citação sobre a educação do campo, fica muito vago. (PI)

Não, eu acredito que não, porque assim [...] nós trabalhamos textos, mas os textos não foram especificadamente para se trabalhar com os alunos do campo, e sim nas aulas, o professor sempre buscava fazer relações, seria o acesso que tinha que se trabalhar a zona urbana. (PII)
}

Os depoimentos citados apontam para a ausência de formação acerca da temática, durante a graduação. O depoimento de PI é claro, no que diz respeito ao esquecimento da educação do campo, de como o campo é ignorado, tanto na formação inicial, quanto continuada. 
No depoimento da PII nota-se também essa ausência, o que mostra que por mais que estejamos discutindo e produzindo conhecimentos no âmbito da academia, dos movimentos sociais e dos comitês da educação do campo nos Estados, nos últimos vinte anos esse debate ainda não chega ao contexto formativo dos docentes.

Em relação a uma alternativa para a formação que contemple a introdução do professor em novas perspectivas, Imbernón explicita:

\begin{abstract}
A solução não está em aproximar a formação dos professores e do contexto, mas, sim, em potencializar uma nova cultura formadora, que gere novos processos na teoria e na prática da formação, introduzindo-nos em novas perspectivas e metodologias (2010, p. 40).
\end{abstract}

Contudo, percebe-se que, para se pensar em uma formação que contemple a educação do campo e que atenda aos seus sujeitos, às exigências que emergem e que são inerentes às suas especificidades, é preciso que se potencialize outra cultura formativa.

No que concerne à formação continuada, ao serem indagadas sobre a existência de formação continuada específica para a educação do campo, as professoras PI e PII afirmam, respectivamente:

Não. No PNAIC (Pacto Nacional pela Alfabetização na Idade Certa) é que a gente está vendo mais, porque é uma sala separada só para os professores que atuam na educação do campo. A gente não junta, não mistura educação do campo com a educação da cidade. É separada. Todos os setores de educação do campo, a gente fica numa sala só, aí sim, a gente assim participa muito, vê o que um está dando na sala, o que a gente está dando transmite para o outro [...]. A gente sempre está interagindo, e é tudo voltado para a educação do campo, a gente procura atividades que voltem sempre para a educação do campo, aí o pacto é que está ajudando mais. (PI)

Não. Porque nas minhas formações eu nunca optei para realmente a educação do campo, embora que a instituição, ela oferecesse, mas nunca me interessei nem nunca imaginava que eu iria passar por uma situação dessas, para mim está sendo novo. (PII)

Os depoimentos citados ressaltam a inexistência da formação continuada que reconheça as especificidades da educação do campo, embora P1 sinalize as contribuições que o PNAIC (Pacto Nacional pela Alfabetização na Idade Certa) tem trazido por meio de formações que sinalizam para a educação do campo a partir de 2014. Contudo, a ausência quanto à formação continuada foi pontuada em ambos os depoimentos.

Quando inquiridas se havia alguma orientação sobre os conteúdos a serem trabalhados, as docentes relataram:

$\mathrm{Na}$ verdade a gente recebe só o livro, o livro didático para trabalhar o ano todo (PI). 
Foi uma das coisas que eu senti dificuldades, por conta que eu não recebi livros, então foi por minha conta, [...] fui pegando os conteúdos, pegando vários livros que eu já tinha e fui associando, e eu mesmo por minha conta, fui preparando os conteúdos. Não que isso me atrapalhou, eu acho que contribuiu, mas, acho que o tempo foi muito curto, que eu queria dá bem mais o que eles necessitavam (PII).

PI e PII afirmaram não haver orientações específicas quanto aos conteúdos a serem trabalhados e, nessa perspectiva, não foi encontrada relação alguma entre o conteúdo e as especificidades da educação do campo.

Quanto à relação entre formação e o currículo, Santos e Almeida (2012) afirmam:

No campo da Educação, os paradigmas atuais direcionam-se para a busca da formação de um novo profissional de um novo cidadão. Como essas idéias paradigmáticas não estão bem definidas, os educadores não sabem o que fazer na sala de aula ou definir o currículo o que precisa ser aprendido significativamente (SANTOS e ALMEIDA, 2012, p. 152).

A explicitação das participantes e dos autores citados mostra que as docentes precisam que se constitua um currículo no qual os conteúdos/saberes sejam tratados de forma equânime no que tange aos saberes escolares e não escolares.

Quando interpeladas sobre a compreensão que tinham a respeito da integração de saberes. as docentes responderam:

O que eu conheço mais ou menos por integração dos saberes é o compartilhamento de saberes, interagir, o que eu faço dentro da sala. Procuro interagir com eles, colocar o conteúdo de acordo o que eles fazem, o que eles veem no campo. E quando eu faço isso percebo que a aula fica assim, mais prazerosa porque eles se identificam [...] (PI).

[...] quando eu vim lecionar, fiquei preocupada com a seguinte questão: qual era o conhecimento que eles tinham e o que eu poderia trazer? Então procurei fazer uma sondagem das coisas, comecei a fazer perguntas: como era o contato deles? O que faziam, para poder rever a minha prática e associar com a deles, para não ter aquele choque (PII).

Os depoimentos das professoras possibilitam a retomada do conceito de integração dos saberes de Lima (2014), já citado, que corrobora com o fato de que falta compreensão e elementos que permitam, aos professores, materializar a integração de saberes.

A aproximação com o campo de pesquisa possibilitou identificar fragilidades formativas em relação às particularidades, especialmente no que concerne ao trabalho com: metodologia da alternância, integração de saberes, constituição de currículo voltado para a realidade do campo, além de outras temáticas.

Diante do exposto, é razoável afirmar que a formação de professores do campo, tanto inicial quanto continuada, se distancia do conceito da educação do campo, bem como, da 
integração de saberes, apesar de tanto a legislação, quanto a produção de conhecimento nesse domínio advirem da transição do século XX para o XXI e do fato de esta continuar a demandar a constituição de políticas educacionais que contemplem a referida modalidade da educação, a partir do paradigma da educação do campo, pautado pelos trabalhadores e pela perspectiva da integração de saberes.

\title{
Integração de Saberes: do Marco Regulatório Às Atividades Didáticas - QUe indícios encontramos nas Práticas Docentes?
}

Ao eleger a integração dos saberes na prática docente da educação do campo como objeto de estudo, ressalta-se, ainda, a necessidade de articulação entre a integração dos saberes e a prática docente. Para tanto, optou-se por analisar atividades didáticas realizadas por alunos das turmas multisseriadas observadas e o diário da PII à luz do marco regulatório.

Quando questionadas se relacionavam os conteúdos trabalhados com a realidade dos alunos, PI e PII afirmaram que sim e a partir disso buscou-se indícios dessa relação, por meio da análise documental, tomando por base as produções dos alunos, tratadas por Lüdke e André (1986), como documento pessoal.

Tomando como critério os indícios de integração de saberes, foram selecionadas 12 atividades dos cadernos dos alunos, no entanto, sendo que apenas três foram consideradas, por apresentarem indícios de integração, contando, sobretudo, com elementos da realidade. Para além dessas atividades, selecionaram-se dois extratos do diário da PII, totalizando cinco atividades tratadas.

Para referenciar o conceito de realidade, tomou-se como base a acepção de Skovsmose, ao tratá-la como "(...) atividade educacional com referências à vida real” (2014, p. 56). Ou seja, a problematização está presente por meio da pesquisa e do envolvimento dos sujeitos, enquanto atores/autores sociais que vivenciam a realidade a partir das proposições apresentadas e de maneira significativa.

Também foi baliza o conceito de realidade de Lima (2014), ao afirmar que:

\begin{abstract}
As referências à realidade representam muito mais que anunciar algo do conhecimento dos(as) alunos(as). Trata-se de problematizar uma situação e criar um cenário de investigação, de forma que os alunos se identifiquem e encontrem significado na realidade que vivem. Deste modo, podem ser motivados a resolvê-la e buscar explicações (LIMA, 2014, p. 43).
\end{abstract}

Considera-se essencial apresentar o conceito de realidade fundamentado em Skovsmose (2014), por se compreender que a análise das atividades didáticas que serão tratadas a seguir têm por base as referências de semirrealidade e de realidade.

A referência de semirrealidade é tratada por Skovsmose (2008) como um cenário que envolve elementos do contexto, mas não se pauta na investigação de seus produtos. Ou seja, a situação não é problematizada, caracterizando-se como uma situação artificial. 
Já a referência de realidade é apresentada, por ele, como cenário investigativo, em que "[...] alunos e professores podem trabalhar tarefas com referências a situações de vida real" (SKOVSMOSE, 2014, p. 22). Nelas os sujeitos educativos são provocados a construir significados e a se tornarem sujeitos ativos no desenvolvimento de suas atividades, articuladas aos contextos em que estão inseridos.

Considerando a referência de semirrealidade, passa-se a analisar o que solicita a primeira atividade entre as selecionadas, como apresentado a seguir.

Atividade solicitada para os alunos dos $4^{\circ}$. e $5^{\circ}$. anos: "Represente sua comunidade em forma de desenhos":

Figura 1: Atividade do caderno do aluno da professora PI.

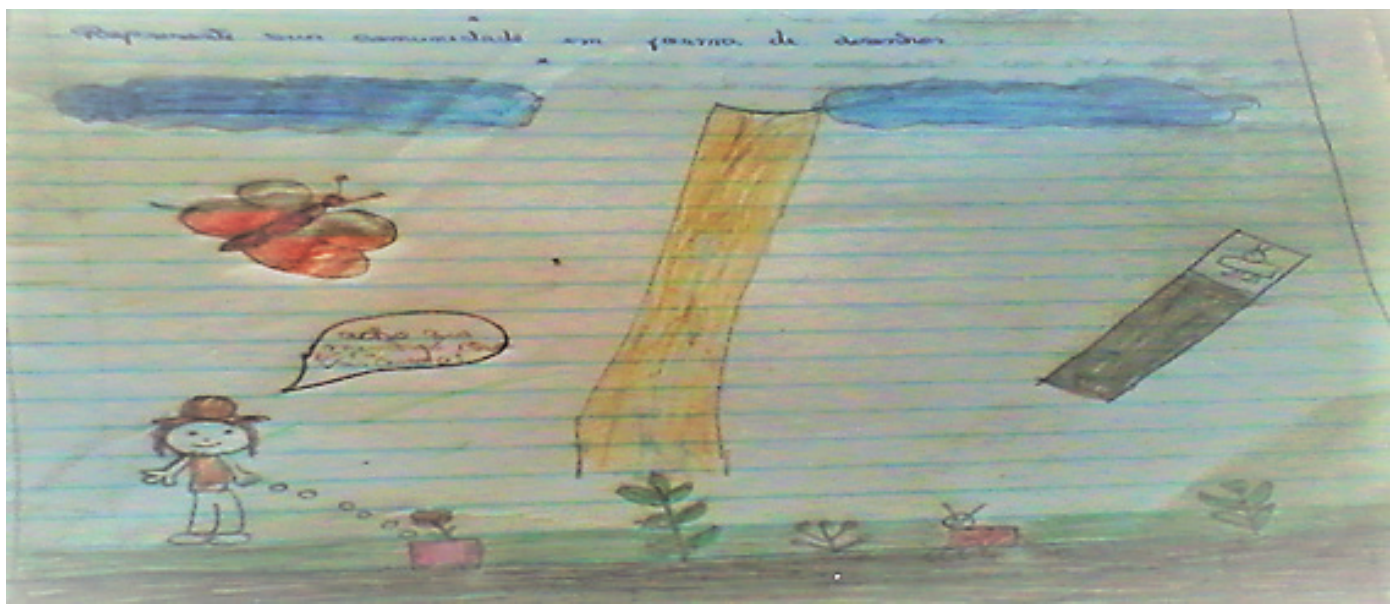

Fonte: Caderno do aluno, $4^{\circ}$. ano, PI, atividade 1.

O enunciado dessa atividade, bem como, a produção do aluno possibilita a leitura de que elementos da realidade têm chegado à sala de aula ao retratá-la no cenário produzido, conforme descrição da atividade citada: um agricultor plantando; uma estrada; uma plantação à margem da estrada; os animais, borboleta e cachorro.

Esse cenário aponta para a compreensão de que esses são elementos da realidade da população dessa escola, visto que a agricultura é o que produz a subsistência de parte dos sujeitos e seus elementos têm chegado à sala de aula. No entanto, ao conceber-se o conceito de realidade a partir da perspectiva de Skovsmose (2014), infere-se que os alunos precisam se envolver e encontrar significado no que fazem.

Para tanto, é preciso que tragam suas intenções, investiguem e as explorem de forma consciente. Tratá-la por esse ângulo é conceber os sujeitos educativos (professores e alunos), como atores/autores ativos no processo, que atuam no contexto real e constroem aprendizagens significativas.

Nessa perspectiva, a atividade apresentada, de fato, traz elementos da realidade. Mas, ao nos referenciar em Skovsmose $(2008,2014)$ e Lima (2014), não a concebemos dentro dos critérios de referência de realidade mostrada pelos autores, tendo em vista que não se

Comunicações | Piracicaba | v. $26 \mid$ n. $1 \mid$ p. 115-141 | jan.-abr. 2019 
criam cenários investigativos, que propiciem aos sujeitos uma atuação em contexto real. Nesse sentido, enquanto atividade proposta, ela tem características de atividade que se pauta na referência da semirrealidade, considerando que a mesma foi elaborada pela professora, com elementos da realidade dos sujeitos, mas que esta não foi problematizada.

Identificou-se que na proposta há apenas a solicitação/explicitação dos instrumentos utilizados no cenário produtivo na comunidade, o que não chega a constituir uma relação entre os saberes escolares e o estilo de vida, a cultura do lugar. Do ponto de vista do marco regulatório, identificou-se a Resolução $\mathrm{N}^{\circ}$. 2, de 28 de abril de 2008, que sinaliza que: "A organização e o funcionamento das escolas do campo respeitarão as diferenças entre as populações atendidas quanto à atividade econômica, seu estilo de vida, sua cultura e suas tradições" (BRASIL 2013, p. 276).

O marco legal citado aponta para a necessidade de se respeitar as escolas do campo em relação às formas de vida, ao estilo e cultura local. Diante dos apontamentos das Diretrizes Operacionais para a Educação Básica nas Escolas do Campo, destacam-se a necessidade de envolver no funcionamento das escolas do campo, a consideração às práticas sociais do local - o que diante da análise da atividade realizada ainda não identificamos.

Na segunda atividade analisada, identificou-se que a solicitação é referente a algo que é escasso na comunidade: a água, como se observa a seguir.

Atividade solicitada: "Desenhe situações nas quais você pode encontrar água":

Figura2: Atividade do caderno do aluno da PI

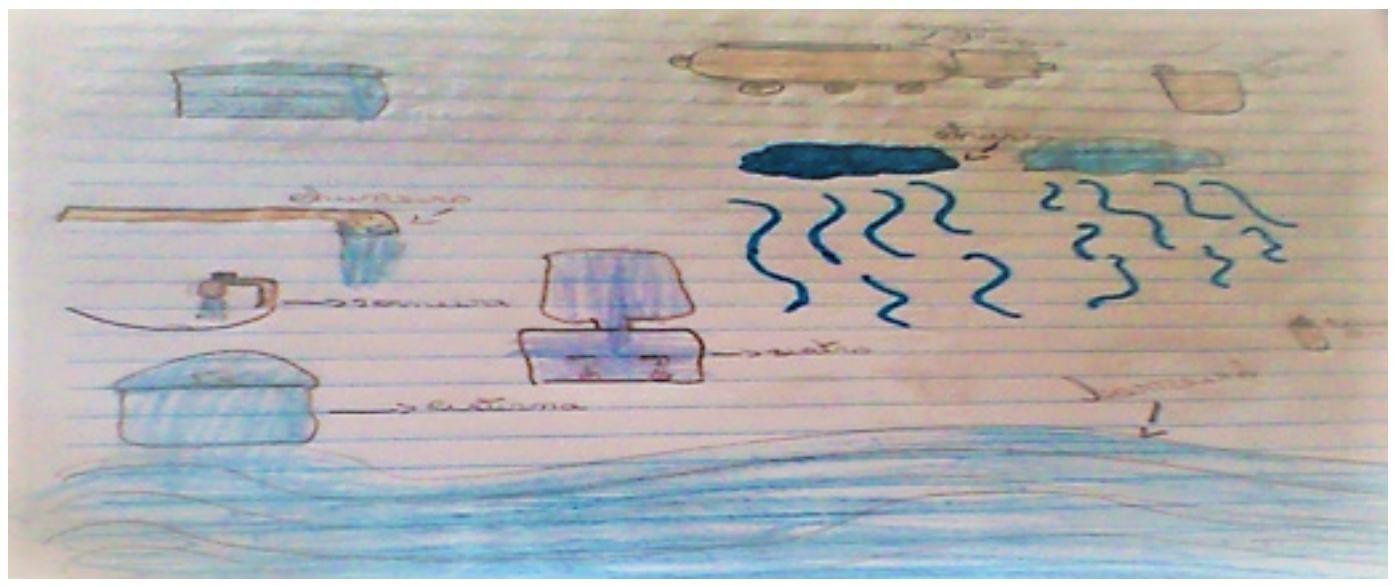

Fonte: Caderno de aluno, $4^{\circ}$. ano, PI, atividade 2.

Conforme enunciado, a atividade solicita que se desenhe os locais em que se encontra água na população local. Os alunos representam: chuva, caminhão de água, caixa, chuveiro, cisterna, torneira, barreiro, filtro, balde de água.

A atividade proposta corresponde a uma atividade marcada por um conteúdo escolar empobrecido, considerando que o contexto é utilizado apenas para identificar a localização. 
A atividade é estanque. Não suscitou em que condições vive a comunidade com esse recurso, essencial à vida, nem as condições de seu uso na comunidade local, no país e no mundo.

A produção do aluno expressa um bem que é comum à população, mas se apresenta de forma escassa em sua realidade, o que exige dos mesmos, diferentes possibilidades de armazenamento, bem como, sua aquisição - demonstrando que novamente, segundo Skovsmose (2014) e Lima (2014), tem-se a referência da semirrealidade. Dessa forma, a referida atividade se pauta nessa referência, considerando que não se propõe a problematização da água no contexto vivido, a partir do significado que esta pode ter para os sujeitos envolvidos (alunos, professores).

No que tange à integração de saberes, nota-se a ausência da contextualização das informações apresentadas pelos alunos, bem como, do conteúdo curricular trabalhado, ou seja, os saberes escolares. Diante do exposto, a representação feita com ilustrações identificadas com seus respectivos nomes, por si só não mostra indícios de integração de saberes, não chega a estabelecer relações entre os saberes socialmente construídos pelos alunos e os saberes escolares.

Articulando a proposição da atividade citada, com o marco regulatório, identifica-se o Decreto $\mathrm{N}^{\circ}$. 7.352 , de 4 de novembro de 2010 , no seu artigo $6^{\circ}$., que sinaliza que:

Os recursos didáticos, pedagógicos, tecnológicos, culturais e literários destina-
dos à educação do campo deverão atender às especificidades e apresentar conte-
údos relacionados aos conhecimentos das populações do campo, considerando
os saberes próprios das comunidades, em diálogo com os saberes acadêmicos
e a construção de propostas de educação no campo contextualizadas (BRASIL,
2010; grifos do autor).

A análise das atividades didáticas trabalhadas até então, articulada ao marco legal, mostra a ausência no tratamento da integração de saberes necessários ao currículo escolar da educação do campo. Os indícios de integração de saberes inicialmente identificados não se consolidaram, considerando que os saberes advindos do currículo, precisariam ser explicitados na condição de ensino e se revelarem na condição de aprendizagem - o que de fato não aconteceu.

As orientações encontradas nos cadernos da SECAD sinalizam que "[...] a adequação dos conteúdos às peculiaridades sociais, o uso de práticas pedagógicas contextualizadas [...]" (HENRIQUES et al., 2007, p. 17) são necessárias à articulação curricular, sugerindo o desenvolvimento de práticas pedagógicas contextualizadas e referenciadas na realidade.

Em outra atividade selecionada do caderno do aluno da PI, identificam-se questões que tratam da "relação dos alunos com a terra". Apresenta-se, a seguir, a imagem da atividade com sua transcrição: 
Figura 3: Atividade do caderno do aluno de PI.

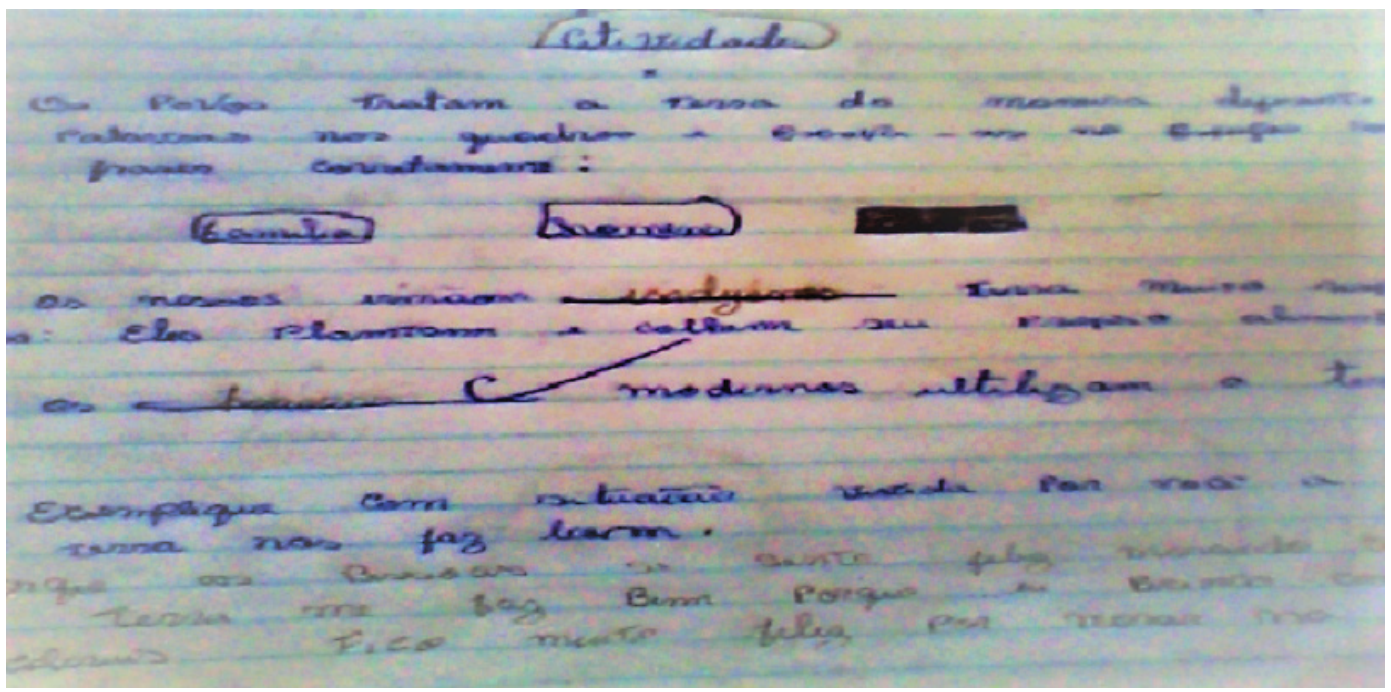

Fonte: Caderno de aluno, $5^{\circ}$. ano, atividade 3, PI.

Transcrição da atividade:

\begin{abstract}
Atividade - Bom (conceito atribuído pela professora)
Os povos tratam a terra de maneiras diferentes, observe as palavras nos quadros e escreva-as nos espaços completando as frases corretamente: família-homem - índio. Os nossos irmãos indígenas têm muito respeito pela terra: eles plantam e colhem seu próprio alimento.

Os homens modernos utilizam a terra.

Exemplifique com uma situação vivida por você a qual mostre que a terra nos faz bem.

$\mathrm{R}$ : Porque as pessoas se sente feliz morando na Terra me faz bem porque eu brinco com areias Fico muito feliz por morar na terra" (Transcrição da Figura 3: Atividade do caderno do aluno de PI, nov., 2014; grifos do autor).
\end{abstract}

Conforme o enunciado, o objetivo da atividade é identificar os diferentes modos como cada povo trata a terra, quando indireta ou implicitamente pede que complete as frases, com os nomes das diferentes representações sociais, que expressam modos distintos de relação com o solo, além de pedir que seja exemplificada a relação que o aluno apresenta com o mesmo, por meio dos relatos vividos.

Embora a atividade insira o aluno enquanto sujeito do contexto, classifica-se, segundo Skovsmose (2014) e Lima (2014), com a referência da semirrealidade, considerando a ausência de problematização, de investigação, e o nível de artificialidade da atividade. Apesar da tentativa da PI de inserir o aluno como sujeito, a resposta vem de maneira superficial mesmo a PI tendo atribuído à atividade o conceito bom. Considera-se ainda que o contexto utilizado na atividade tenha relação com os saberes históricos das sociedades. No entanto, em uma perspectiva de integração de saberes, identificou-se a necessidade de um acesso aos conteúdos da área das ciências humanas, de forma a aprofundar a relação entre os sa- 
beres escolares e as atividades do local, que se reverberem no processo de construção do conhecimento dos sujeitos, em que ele (aluno) é sujeito do processo formativo e identitário.

A relação dos povos com a terra é relevante ao considerar o contexto no qual os alunos estão inseridos. Dessa forma, observar essa relação é remeter-se à sua própria história de vida considerando a herança cultural que receberam, como ressalta Passos e Melo (2012):

Para tornarem-se sujeitos sociais, o processo de formação dá-se em diferentes
momentos, a começar pela história de cada um, de suas famílias, do lugar onde
vivem, do saber que historicamente vem sendo construído a partir da herança
cultural e dos saberes oriundos de seus ancestrais repassados de geração a ge-
ração (PASSOS e MELO, 2012, p. 247; grifos do autor).

Conforme explicitam as autoras, a formação dos alunos se dará por meio das influências pelas quais passam, tornando seus conhecimentos resultados dessa interação. Mas, há a necessidade de que as atividades propostas se relacionem aos saberes historicamente construídos, o que do nosso ponto de vista fica aquém na atividade proposta ao se trabalhar a área de conhecimentos das Ciências Humanas, o que não apresenta indícios de integração de saberes.

Na perspectiva do marco regulatório, a educação do campo tem a função de promover o desenvolvimento humano, partindo de suas próprias experiências, como esclarece o Parecer CNE/CEB No. 23/2007.

Não se trata, é claro, da idéia (sic) errônea de pretender fixar o homem rural no campo, uma vez que o processo educativo deve criar oportunidades de desenvolvimento e realização pessoais e sociais; trata-se, entretanto, de trabalhar sobre as demandas e necessidades de melhoria sob vários aspectos [...] (BRASIL, 2008, p. 2; grifos do autor).

Com essa afirmação, notou-se que os processos educativos desenvolvidos no campo necessitam promover o desenvolvimento dos seres humanos a partir de suas experiências e da ampliação do conhecimento, sem a intenção de fixá-lo no campo, mas contribuindo para que, pela via de uma formação emancipatória, escolha o lugar onde quer viver, sem negar ou subalternizar sua identidade, bem como, suas raízes sociais, culturais e políticas.

O primeiro extrato do diário da PII, selecionado a seguir, destaca a questão da sociedade por meio do estudo de diferentes grupos sociais:

Figura 4: Extrato do diário da PII.

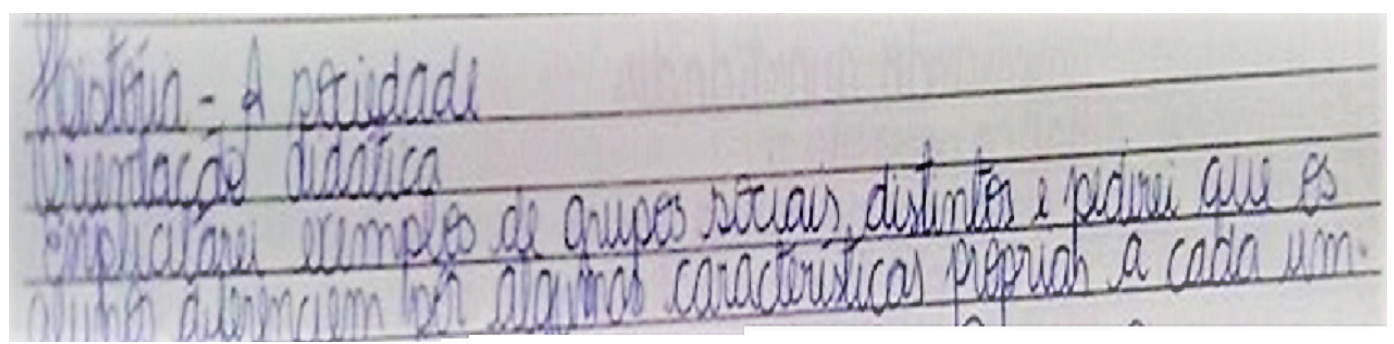

Fonte: Extrato do diário da PII. 
O registro de aula apresenta uma situação do ponto de vista curricular, para ser tratada no âmbito das Ciências Humanas. Vejamos: "História - A sociedade. Orientação didática. Explicitarei exemplos de grupos sociais distintos e pedirei que os alunos diferenciem por algumas características próprias a cada um". (Transcrição da Figura 3 - Extrato do registro de aula, PII.)

Identificou-se no registro do diário da PII, na Figura 4, uma relação com a Figura 3, ou seja, se na última tem-se o registro do que vai ser trabalhado: "A sociedade", na Figura 3 tem-se o trato de elementos da sociedade: "A terra, o índio, o homem moderno". Na articulação entre as Figuras, vê-se a tentativa de promover a interação com grupos sociais distintos, quando "sugere que os alunos expressem exemplos de grupos sociais e os diferenciem pelas suas principais características". Contudo, entende-se que essa questão foi tratada de maneira generalizada, ampla, aberta demais, sem contemplar a interação entre o conteúdo/ saber escolar e a comunidade local.

Em outro extrato do diário da PII, identificou-se o registro do que será trabalhado, com foco na ação do ser humano na natureza, conforme segue:

Figura 5: Extrato do diário da PII.

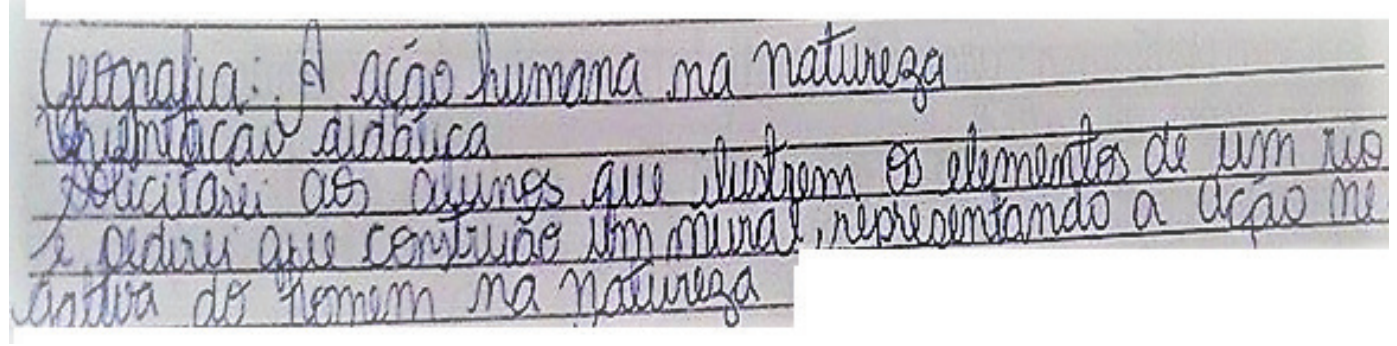

Fonte: Extrato do diário da PII.

O registro de aula da PII apresenta uma situação didática em que se identifica: "Geografia: A ação humana na Natureza. Orientação didática - Solicitarei aos alunos que ilustrem os elementos de um rio e pedirei que construam um mural, representando a ação negativa do homem na natureza" (Extrato do diário da PII).

Identificou-se que a atividade pode ser caracterizada pela referência da semirrealidade (LIMA, 2014), pois, embora tematize a relação ser humano - natureza, configura-se como uma proposta de atividade envolvendo uma relação estática, portanto, não problematizada, sem relação de significação.

No entanto, ficou evidente que, os diferentes espaços de convívio dos alunos são espaços educacionais e o incremento do diálogo com essas diferentes representações é fundamental para a promoção do conhecimento, na perspectiva da integração dos saberes.

Conforme a Resolução CNE/CEB N ${ }^{\circ}$. 1, de 3 de abril de 2002, as propostas pedagógicas devem favorecer a reflexão quanto às situações no campo de forma a efetivar a interação entre o ensino (conteúdos escolares) e a sua diversidade, integrando a escola ao estudo dos acontecimentos que modificam o campo. 
Nessa perspectiva, a consciência da ação favorece ao ser humano o conhecimento. A esse respeito, Borges (2012, p. 81) afirma que “[...] o ser humano pode se tornar consciente ao detectar as contradições sociais entre as representações e suas atividades desempenhadas na produção da vida material (as condições de vida que o mundo do trabalho lhe oferece)".

É com base no acesso à diversidade e nas modificações que vão ocorrendo no campo que os sujeitos vão se apropriando e tomando consciência também das contradições presentes em suas condições de vida, possibilitando, assim, que os sujeitos se conscientizem de sua ação no mundo.

Diante do exposto, e já a caminho da conclusão, compreende-se que na perspectiva do marco regulatório, identifica-se na Resolução $\mathrm{N}^{\circ}$. 2, de 28 de abril de 2008, orientações quanto ao respeito às particularidades das populações do campo, enquanto o Decreto $\mathrm{N}^{\circ}$. 7.352 , de 4 de novembro de 2010, sinaliza que os recursos dedicados às escolas do campo devem acolher suas especificidades e o currículo considerar os saberes próprios das comunidades em diálogo com os saberes acadêmicos.

Já de acordo com o Parecer CNE/CEB No. 3, de 18 de fevereiro de 2008, o processo educativo há de criar oportunidades de desenvolvimento e realização pessoais e sociais. A Resolução CNE\CEB N ${ }^{\circ}$. 1, de 3 de abril de 2002, afirma que a identidade da escola do campo é definida pela sua vinculação às questões inerentes à sua realidade e que as propostas pedagógicas as valorizem; além de ressaltar que na organização do ensino, a diversidade cultural e os processos de interação e transformação do campo precisam ser levados em conta, explicitando assim que o marco regulatório apresenta indicativos para a efetivação da integração dos saberes nas escolas do campo.

Com base nos dados já tratados, bem como, a partir dos teóricos que fundamentam a pesquisa, pode-se concluir que nas atividades didáticas e registros de aula analisadas encontram-se elementos de saberes socialmente adquiridos pelos alunos, ainda concentrados em uma perspectiva de semirrealidade (LIMA, 2014). Dessa maneira, nota-se a falta de articulação com os conteúdos escolares, apontando apenas para indícios de elementos da realidade concebidos como semirrealidade - o que mostra que, de fato, a integração de saberes ainda não está presente no contexto ora pesquisado.

\section{CONSIDERAÇões FINAIS}

O mobilizador para o desenvolvimento desta pesquisa foi a busca pela especificidade da educação do campo, com foco na integração dos saberes, tratada a partir das práticas das docentes e, para tanto, procurou-se compreender como a integração dos saberes é tratada no cotidiano das escolas do campo e identificar o saber das docentes do campo sobre a integração dos saberes, além de analisar nas atividades didáticas produzidas os elementos perceptíveis da integração dos saberes; e levantar no marco regulatório indicativos da integração de saberes.

A análise dos dados revelou que há um distanciamento, por parte das professoras, entre o trabalho e a perspectiva da educação do campo no que se refere ao entendimento sobre integração de saberes. 
Embora a formação docente não tenha sido o foco da pesquisa, a reflexão a respeito dela é inevitável porque detectou-se a ausência de tratamento dessa temática no processo formativo das docentes, tanto na formação inicial, quanto na continuada, além de se identificar nas falas sobre a formação, a presença de uma concepção de educação mais próxima da ideia de educação rural ${ }^{1}$ do que da, desejável, educação do campo.

Com relação à compreensão do que seja integração de saberes, evidencia-se, ainda, que o conceito não é suficientemente claro o que pode ser um impeditivo para que essa integração se instale na prática docente.

A ambiguidade notada no conceito, bem como, na articulação entre os saberes curriculares propostos a partir das áreas de conhecimento e os saberes não escolares, sugere a necessidade de se investir em políticas de formação que respondam não só às demandas curriculares, mas também à formação inicial e continuada, à integração de saberes, à alternância pedagógica, entre outras especificidades da prática docente na educação do campo.

Por meio da observação participante, na aproximação da prática docente, para o levantamento dos aspectos da integração de saberes emerge, como questão, a partir desta pesquisa, compreender de que forma se procede às orientações para a adoção de conteúdos pelos docentes da educação do campo, visto que as entrevistadas pontuaram a inexistência de instruções e diretrizes sendo elas as responsáveis pela seleção do que trabalhar - o que aponta para a ausência de um currículo que contemple a articulação dos saberes escolares aos não escolares.

A análise das atividades revelou que nas propostas, não se constitui uma legítima e robusta relação entre os saberes escolares e os populares, necessário em virtude do estilo de vida e da cultura do lugar, embora nas orientações oficiais identifique-se a exigência ao respeito que as escolas do campo devem disseminar em relação às atividades, ao estilo e cultura local de seus sujeitos.

Os elementos do contexto que chegam às atividades didáticas, na sala de aula, primam por basear-se na semirrealidade, o que indica a premência de problematização, significação, contextualização das informações apresentadas e o conteúdo curricular trabalhado para que de fato a realidade chegue ao currículo e que, pela via da integração de saberes chegue à sala de aula.

$\mathrm{Na}$ análise dos textos oficiais sobre educação do campo, há indicativos da integração dos saberes por meio dos apontamentos que ressaltam a realidade do campo, o desenvolvimento social, o respeito às particularidades do campo, a proposta de diálogo entre os saberes da comunidade e os saberes acadêmicos, ou seja, são identificáveis no marco regulatório, os indicativos da integração de saberes no âmbito do currículo escolar das escolas do campo e das práticas docentes.

\footnotetext{
1 A educação rural é aqui tomada como uma educação que subordina a população camponesa à da área urbana. Nessa perspectiva, resta à população camponesa as sobras da área urbana. A educação para essa população, é compensatória, e pensada por outros, que se encontram numa condição superior. Seus sujeitos são subalternizados aos que vivem na área urbana. Suas escolas têm o ensino, a infraestrutura e os/as profissionais da educação frágeis, seus alunos pouco aprendem. A educação rural é, na acepção de Ribeiro (2012, p. 293), "Destinada a oferecer conhecimentos elementares de leitura, escrita e operações matemáticas simples [...]".
} 
Com base nos dados, centrados nas atividades dos alunos e registros de aulas, encontram-se elementos referentes aos saberes socialmente construídos pelos alunos. No entanto, notou-se a falta de articulação dos mesmos com os conteúdos escolares, identificando apenas um dos elementos que possibilitam a integração: os saberes populares.

Os achados da pesquisa revelaram a necessidade do desenvolvimento de práticas docentes em escolas do campo referendadas nas especificidades da concepção de Educação do Campo e no trabalho com a integração dos saberes, bem como a inserção dessa perspectiva no processo formativo dos professores dessa modalidade, tanto na formação inicial quanto continuada.

Até então, exceto as licenciaturas em Educação do campo no Brasil, que demarcam a formação inicial de professores e o Programa Escola da Terra (2014), a formação continuada, não se identificam outras proposições, a partir da federação, que articulem ações focadas na formação de professores/as do campo, explicitando que os fatores macro (políticos, sociais e econômicos), continuam incidindo sobre a população campesina. Na medida em que se tem apenas um Programa de formação inicial e outro para a formação continuada, em um país com extensão continental e com a diversidade de povos do campo que temos, no conjunto das cinco regiões brasileiras, se descortina o não comprometimento e priorização de políticas públicas para com essa população, que historicamente tem os seus direitos negados. Esses fatores interferem diretamente na realidade educacional brasileira, com implicações na não materialização da educação do campo, e por conseguinte na integração de sabres.

Ressalta-se, ainda, que a integração dos saberes, enquanto parte constituinte da Educação do campo, poderá potencializar pela via do trabalho pedagógico o acesso da população campesina aos conhecimentos científicos, que articulado aos populares, possibilitará um repertório de conhecimentos, que alavanque sua atuação, rumo à transformação da realidade social em que vivem.

Por fim, conclui-se que a integração de saberes necessita de uma discussão mais aprofundada, o que remete à relevância da continuidade deste debate em futuras pesquisas.

\section{REFERÊNCIAS}

ARROYO, M.; CALDART, R. S.; MOLINA, M. C. (orgs.). Por uma educação do campo. Petrópolis, RJ: Vozes, 2004.

BARDIN, L. Análise de Conteúdo. Trad. de Luís Antero Reto, Augusto Pinheiro, 3. ed. São Paulo: Edições 70 Lisboa, 2004.

BORGES, H. S.; SILVA, H. B. A Educação do Campo e a organização do trabalho pedagógico. In: GHEDIN, Evandro (org.). Educação do Campo Epistemologia e práticas. São Paulo: Cortez, 2012. 
BRASIL. Ministério da Educação. Secretaria de Educação Continuada Alfabetização e Diversidade. (SECAD) Educação do Campo: diferenças mudando paradigmas. Brasília, DF 2007. Disponível em: <http://portal.mec.gov.br/secad/arquivos/pdf/educacaocampo. pdf $>$ Acesso em: 16 jun. 2015.

. DECRETO No. 7.352, de 4 de novembro de 2010. Disponível em: <http://www. planalto.gov.br/ccivil> Acesso em: 19 nov. 2014.

. Lei de Diretrizes e bases da Educação Nacional. Lei no $.9 .394 / 96,10$. ed. Rio de Janeiro, 2006.

. PARECER CNE/CEB No. 23/2007, 19 de setembro de 2007. Disponível em: $\overline{<\mathrm{http}: / / p o r t a l . m e c . g o v . b r / c n e / a r q u i v o s / p d f / 2007 / p c e b 023 \_07 . p d f>}$ Acesso em: 29 mai. 2015.

. PARECER CNE\CEB No. 3\2008, 18 de fevereiro de 2008. Disponível em:

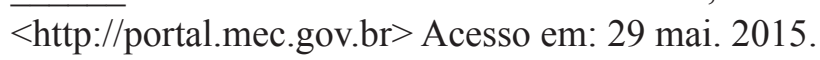

. Ministério da Educação. Secretaria de Educação Continuada Alfabetização e Diversidade. Cadernos Pedagógicos Projovem campo - Saberes da Terra. Brasília DF, 2008 .

. RESOLUÇÃO CNE/CEB 1, DE 3 DE ABRIL DE 2002. Disponível: <http:// portal.mec.gov.br> Acesso em: 13 mai. 2015.

. RESOLUÇÃO No . 2, DE 28 DE ABRIL DE 2008. Disponível em: <http://portal. mec.gov.br/cne/arquivos/pdf/2008/rceb002_08.pdf> Acesso em: 29 mai. 2015.

CALDART, R. S. Educação do Campo. In: CALDART, R. et al. (org.). Dicionário da educação do campo. Rio de Janeiro: Escola Politécnica de Saúde Joaquim Venâncio. São Paulo: Expressão Popular, 2012, p. 259-267.

FREIRE, P. Pedagogia da autonomia: saberes necessários a prática educativa. São Paulo: Paz na terra, 1996.

GIESTA, N. C. Cotidiano escolar e prática reflexiva do professor: moda ou valorização do saber docente? Araraquara: JM editora, 2001.

HENRIQUES, R. et al. Educação do Campo: diferenças mudando paradigmas. Brasília, DF, 2007. Disponível em: <http://portal.mec.gov.br/secad/arquivos/pdf/educacaocampo.pdf> Acesso em: 16 jun. 2015. 
IMBERNÓN, F. Formação Continuada de professores. Porto Alegre: Artmed, 2010.

KOLLING, Edgar Jorge (org.). Educação do Campo: identidade e políticas públicas. Brasília, DF: Articulação Nacional por uma Educação do Campo, 2002.

LIMA, A. S. de. Educação do campo e educação matemática: relações estabelecidas por camponeses e professores do agreste e sertão de Pernambuco, 2014, 140s. Dissertação (Mestrado em Educação Contemporânea) Universidade Federal de Pernambuco-UFPE - Centro Acadêmico do Agreste-CAA, Caruaru.

LÜDKE, M.; ANDRÉ, M. D. A. Pesquisa em educação: abordagens qualitativas. São Paulo: EPU, 1986.

MINAYO, M. C. S. A pesquisa qualitativa. In: MINAYO, Maria Cecília de Souza (org.). Pesquisa social: teoria, método e criatividade, 23. ed. Petrópolis, RJ: Vozes, 1994.

MOLINA, M. C.; SÁ, L. M. Escola do Campo. In: CALDART, R. et al. (org.). Dicionário da educação do campo. Rio de Janeiro: Escola Politécnica de Saúde Joaquim Venâncio. São Paulo: Expressão Popular, 2012, p. 326-333.

OLIVEIRA, M. L.; LIMA, I. M. Integração de Saberes e Metodologias de alternância: Olhar de educadores/as de matemática do projovem campo. Anais do XIX CONIC III CONITI VII JOIC CTG - UFPE, 2011. Disponível em: <www.ufpe.br/propesq/images/ conic/2011/conic/n_pibic/70/117081122SCNO.pdf> Acesso em: 6 mai. 2015.

PASSOS, M. G.; MELO, A. O.; Casa Família Rural da França à Amazônia: uma proposta da Pedagogia da Alternância. In: GHEDIN, Evandro (org.). Educação do campo: epistemologia e práticas. São Paulo: Cortez, 2012, p. 237-250.

RIBEIRO, M. Educação rural. In: CALDART, R. et al. (org.). Dicionário da educação do campo. Rio de Janeiro: Escola Politécnica de Saúde Joaquim Venâncio. São Paulo: Expressão Popular, 2012, p. 293-299.

SANTOS, A. V.; ALMEIDA, L. S. C. Perspectivas Curriculares para a Educação no campo: algumas aproximações para a construção do currículo da escola dos que vivem no e do campo. In: GHEDIN, Evandro (org.). Educação do campo: epistemologia e práticas. São Paulo: Cortez, 2012, p. 137-158.

SKOVSMOSE, O. Desafios da reflexão: em educação matemática crítica. Campinas, SP: Papirus, 2008. 
. Um convite à educação matemática crítica. Campinas, SP: Papirus, 2014.

TEIXEIRA, E. S.; BERNARTT, M. L.; TRINDADE, G. A. Estudos sobre Pedagogia da Alternância no Brasil: revisão de literatura e perspectivas para a pesquisa. In: Educação e Pesquisa, São Paulo, v. 34, n. 2, p. 227-242, mai./ago. 2008. Disponível em: <http://www. scielo.br/pdf/ep/v34n2/02.pdf $>$. Acesso em: 12 jan. 2015.

VASCONCELOS, R. M. O. de. Um olhar sobre a prática docente no ensino médio integrado em uma unidade da Rede Federal de Educação Profissional e Tecnológico em Pernambuco, 2014, 187s. Dissertação (Mestrado em Educação Contemporânea). Universidade Federal de Pernambuco-UFPE - Centro Acadêmico do Agreste-CAA, Caruaru.

\section{Dados das autoras:}

\section{Maria Joselma do Nascimento Franco}

Doutora em Educação pela Universidade de São Paulo. Professora Associada no Programa de Pós-Graduação em Educação Contemporânea da Universidade Federal de Pernambuco. Caruaru/PE - Brasil. mariajoselmadonascimentofranco@gmail.com

\section{Maria Madalena da Silva}

Graduada em Pedagogia pela Universidade Federal de Pernambuco, Campus Acadêmico do Agreste. Caruaru/PE - Brasil. madalenaceru@gmail.com

Submetido em: 18-3-2018

Aceito em: 15-3-2019 